\title{
Impact of Foreign Direct Investment on Economic Growth in Ethiopia
}

\section{Urgessa Firomsa Fite}

Department of Economics, College of Business and Economics, Haramaya University, Addis Ababa, Ethiopia

\section{Email address:}

urgessafiromsa2013@gmail.com, urgessafiromsa63@gmail.com

\section{To cite this article:}

Urgessa Firomsa Fite. Impact of Foreign Direct Investment on Economic Growth in Ethiopia. American Journal of Theoretical and Applied Business. Vol. 6, No. 4, 2020, pp. 72-78. doi: 10.11648/j.ajtab.20200604.14

Received: October 15,, 2020; Accepted: November 9, 2020; Published: November 23, 2020

\begin{abstract}
The aim of the study is to investigate the Impact of Foreign Direct Investment on economic growth in Ethiopia by using annual time series data from the periods of 1982 to 2018. To achieve this objective the Descriptive and Econometric analysis were processed. The Ordinary Least square (OLS) method approach was employed to assess the model in the long run. The empirical results points out that as foreign direct investment has a positive and significant impact on the economic growth of Ethiopia. Beside this other variables such as gross capital formation, gross domestic saving and infrastructural level also have positive and significant contribution on the economic growth and enhance the growth of the country. Error-correction model (ECM) has been used to support the existence of a stable long-term relationship and confirm a deviation from the longterm equilibrium. The finding of error-correction model revealed that there was a deviation of the actual growth of the country from its equilibrium value that eliminated every years and indicates a short run deviation of growth from the long run equilibrium. In doing so, the Diagnostic and Unit root tests were conducted to guard the model from spurious results. Based on the finding of the study the researcher recommended that all concerning bodies to be utilized properly and wisely the opportunity of foreign direct investment out comes as it continues to increase the economic growth and motivate them as they enter in to the country for investment.
\end{abstract}

Keywords: Foreign Direct Investment, Infrastructure, Real GDP, Economic Growth, Ethiopia

\section{Introduction}

Foreign direct investment is one of the key economic features of the modern globalized world. It plays an important role in economic growth. It is also an increasingly important channel for resource flows between the industrial and developing countries. Several real and potential benefits discernible from these flows that include technological spillovers, job creation, improved managerial skills and productivity. Given the capital deficient nature of least developed countries and the benefits accruable from these activities, and it is essential for growth and development. It affects economic growth of developing countries positively through transfer of capital, know-how, and technology [6].

A panel study of China, Japan, India, South Korea and Indonesia using data for 1993 to 2011, [1] investigated the impact of FDI on GDP Growth and report that "FDI promotes economic growth, and further provides an estimate that one dollar of FDI adds about 7 dollars to the GDP of each of the five countries.

In East Africa, FDI increased by 15 percent to 6.2 billion USD because of rising flows to Ethiopia and Kenya. This is due to the increasing integration of developing countries into international trade and the global market as it is accompanied by a dramatic influx of foreign capital into developing countries in the form of FDI. The attitude of many developing countries towards the importance of FDI has changed remarkably and they have taken steps to ease restrictions on FDI inflow. These countries' supportive policies towards FDI base themselves on the assumption that FDI increases the country's output, productivity and technology transfer [3].

Considering the benefits of FDI for growth and development, most African countries have undertaken varies policy reforms to create conducive investment environment in order to attract a considerable amount of FDI. However, although the African continent has made notable efforts to 
attract FDI, the inflows of FDI are very small compared to other developing nations. For instance, among the FDI inflows to developing countries between the periods 2005 to 2010, African share was only around ten percent and also characterized by uneven distribution among countries in the region [14].

Some areas of investment are reserved for domestic investors only. According to Ethiopia's regulation on Investment Incentives and Investment Area Reserved for Domestic Investors (2012), banking service, insurance, postal service, supply of electrical energy, telecommunication service, and broadcasting are some areas reserved for domestic investors [5].

\subsection{Statement of the Problem}

Sustainable economic growth is highly determined by the rate of investment which in turn is mainly determined by the national savings level. The national savings level of countries in Africa is quite low. Foreign direct investment (FDI) is an alternative source of capital to bridge the gap between savings and the required investment level [11].

There are controversial arguments regarding the impact of foreign direct investment on the economic growth of host countries. Although some argue that foreign direct investment is taken as a way out to boost economic growth and development in developing economies, others are concerned with its negative impact on host country.

According to the latter group foreign direct investment (FDI) can destroy local capabilities and extract natural resource without adequately compensating poor countries. Despite this during the past decades countries are recognizing the important role of FDI on economic growth and start to liberalize their FDI regime [15].

There are several studies conducted on the impact of FDI on economic growth. According to [2] capital flows has significant influence on the host country. Financial markets, host country absorptive capacity, human capital and technology are the main channels through which the effects are transmitted. The relationship between FDI and improvement in human development is also more strongly positive when corruption is low [10].

The crucial role of FDI in terms of enhancing capital formation, spillover effects, competition, linkage, technology transfer, and there by incurring development problems has led to the development of several theoretical and empirical literature studies. Some scholars argue that FDI has an adverse effect on growth. They argue increased FDI does not always contribute to upgrading but sometimes may even act to reduce the host country's long run potential, leading to a crowding-out effect where by domestic firms are displaced or outcompeted by foreign-owned multinational enterprises hence affecting economic growth negatively,[12]. Such conflicting evidence is not an exception in the Ethiopian economy. In spite of limited research on the effects of FDI on macroeconomic variables, recent empirical finding shows a negative association between FDI and economic growth in Ethiopia [16].
There are some studies done on the impact of FDI on economic growth of Ethiopia. From those [7] studied the impact of foreign direct investment on the economic growth in Ethiopia with the inflation rate trade balance, foreign direct investment, government expenditure and the findings show that the foreign direct investment has positive impact on the economic growth and statistically insignificant. According to [13] examines the relationship between FDI and domestic private investment using time series data over the period 1970-2012. The study shows that FDI crowds-out domestic private investment and also foreign direct investment does not have a significant effect on economic growth. As [9] empirically analyze the relationship between foreign direct investment and economic growth in Ethiopia from the annual period of 1970-2009. The study uses cointegrated VAR approach. Accordingly foreign direct investment had a negative impact on economic growth. However further studies should be needed to investigate the impact of FDI on economic growth. While the studies undertaken in this area the studies were failed to address as the contributions of foreign direct investment has encourage and pushing economic growth forward and sustain it. Further more comprehensive analysis that includes important variables that has great contributions on the economic growth and FDI inflows to the country such as human capital, infrastructural level, labor force are lacking. This paper attempts to consider these gaps and try to address the impact of foreign direct investment on Ethiopian economic growth over the period 1982-2018 and fill the time gaps not covered by others, by using OLS method for long run because of its convenience and simplicity and ECM in case of short run.

\subsection{Significance of the Study}

The significance of this study was to add one more contribution to the existing literature by analyzing both the separate negative and positive impact of FDI on economic growth. The government and the concerned body may use the recommendation given under this study to improve the necessary conditions for foreighn investors. This study also analyses and depicts the Impact of the FDI inflows on the Ethiopian economic growth and it identifies the growth opportunities that are created due to FDI inflows into the country and the trends of FDI in Ethiopia. In fact, the significance of the study can be to use the findings as one source of information related to FDI and economic growth in the country. In addition, it is a point to fill the gap of literature on the topic.

\section{Objective and Hypothesis of the Study}

\subsection{Objective of the Study}

The general objective of the study was to analyze the impact of foreign direct investment on economic growth in Ethiopia.

Having the above general objective, this study has also the following specific objectives; 
To investigate the relationship between the of FDI and economic growth in Ethiopia.

To examine the contributions of labor force, human capital, infrastructure, gross capital formation, openness and domestic saving on the economic growth.

To assess the trend of FDI in the Country

\subsection{Hypothesis of the Study}

Based on the theoretical aspects and the real feature of the country, the impact of foreign direct investment was described by the following hypothesis:

First, regarding the relationship of variables;

$\mathrm{H}_{0}$ : There is negative relationship between the foreign direct investment and economic Growth in the Country.

H1: There is positive and significant contribution of foreign direct investment on the economic growth.

Second, regarding the nature of time series from;

$\mathrm{H}_{0}$ : Ordinary list square model is not appropriate and

$\mathrm{H} 1$ : Ordinary list square model is appropriate

Third, regarding to the variety of tests for unit roots or stationary of time series;

$\mathrm{H}_{0}$ : Each time series contains a unit root.

$\mathrm{H} 1$ : Each time series is stationary.

\section{Methodology of the Study}

\subsection{Type of Data, Source of Data and Methods of Data Analysis}

The type of data used in this study was secondary time series data (in the period of 1982 to 2018) that was collected from MOFEC (Minister of Finance and Economic Corporation of Ethiopia) and National Bank of Ethiopia (NBE) and Ethiopian Central Statistical Authority (ECSA) for this study. The data has been analyzed using STATA 13 econometrics software. In line with similar studies on FDI and economic growth especially across countries, the study had been developed a linear regression approach in determining the influence and relationship that Foreign Direct Investment has on Ethiopian economic growth. The statistical method has been assessed by the Ordinary Least Square Method (OLS) for long run and error correction model (ECM) for short run.

\subsection{Specification of Model}

Economic growth is the result of and the interaction of many variables. The neo-classical Solow growth model explains economic growth as resulting from the combination of two elements, namely Capital and Labor. The Solow model studies the growth path of economies by assuming a neoclassical production function which combines two factors to produce output capital and labor. Both factors are perfectly substitutable and exhibit diminishing returns to scale [8]. The model was applied by OLS estimation method because of its convenience and simplicity in case of log run and ECM in case of short run analysis. There were various studies include different variables while analyzing the impact of foreign direct investment across the world, here, in this study the model was being specified using Solow Growth model as follows:

$$
\mathrm{GDP}=\mathrm{f}(\mathrm{FDI}, \mathrm{INF}, \mathrm{TRO}, \mathrm{LF}, \mathrm{HK}, \mathrm{GCF}, \mathrm{GDS}, \mathrm{INFS})
$$

Specifically the model is as follows:

$$
\begin{gathered}
\mathrm{GDP}=\beta_{o}+\beta_{1} \mathrm{FDI}+\beta_{2} \mathrm{INF}+\beta_{3} \mathrm{TRO}+\beta_{4} \mathrm{LF}+\beta_{5} \mathrm{Hk} \\
+\beta_{6} \mathrm{GCF}+\beta_{7} \mathrm{GDS}+\beta_{8} \mathrm{NFS}+\mathrm{u}_{\mathrm{i}}
\end{gathered}
$$

\subsection{Explanation of Dependent and Independent Variables}

Based on the above model we can understand the represented name of dependent and independents variable with its description and expected signs.

\subsubsection{Description of Dependent Variable}

GDP (Y) is the market value of the goods and services produced by an economy over time. Since most economists argue that economic growth can be measured as growth in GDP, it includes in the model as main dependent variable in order to measure economic growth. In order to avoid the inconsistency associated with different base year price while computing per capita GDP, this study was used the per capita GDP (constant value).

\subsubsection{Description of Independent Variables and Its Expected Sign}

Foreign Direct Investment (FDI), Foreign direct investment, net inflows (\% of GDP): WB defines FDI as the net inflows of investment to acquire a lasting management interest (10 percent or more of voting stock) in an enterprise operating in an economy other than that of the investor. Inflation rate (INF): is raising general price level. In this analysis inflation rate (based on CPI) will use to measure the effect of macroeconomic stability and low inflation is expected to have a positive marginal influence on FDI inflow. It is negatively affect dependent variables. Trade openness (TRO), a level of trade openness is peroxide by the fraction of the sum of imports and exports in GDP [(Exports + Imports) /GDP]. A positive co-efficient is expected if the level of trade openness positively influences FDI-induced Growth.

Labor force (LF): According to the WB definition, Labor force comprises people ages 15 and older who meet the International Labor Organization definition of the economically active population. It includes people who are currently employed and people who are unemployed but seeking work as well as first-time job-seekers. But this study focuses on the currently employed peoples in the domestic \& foreign investment projects. Working force has direct relation to the GDP. Human Capital (HK) is level of human capacity development measured as expenditure on education in million birr. A positive co-efficient is expected if human capacity development positively influences FDI-induced economic growth.

Gross capital formation (GCF\% of GDP) is consists of outlays on additions to the fixed assets of the economy plus net changes in the level of inventories. It has positive impact 
on the GDP. Gross Domestic Savings (\% of GDP), income is classified as consumption and saving. GDS is income that is not consumed by immediately buying goods and services is saved. This is measured in nominal terms; Constant Birr values.it has positive impact on the GDP. Infrastructure (INFS) The level of infrastructure development is providing by total government development in case of road transportation and communication. A positive co-efficient is expected if the level of infrastructure development positively influences FDI-induced economic growth.

\section{Results and Discussions}

\subsection{Descriptive Analysis}

The result of descriptive statistics of variables is here that the main variables have been described from 1982-2018. From the sample taken in this paper, the highest value of Gross domestic product was recorded between this periods was 8765.675 in million birr. In the country, the lowest value of Gross domestic product was recorded 2534.6 in million birr. In addition to this, the gross domestic product had no uniform trend over the period. Gross domestic product have increased from one period to the other and sometimes declined from period to period depending on the impacts of the independent variables. The standard deviation shows the spread of the values from the mean and is important for comparison purposes. For example the highest deviation was Gross domestic saving, which is 99079.35 while the lowest deviation was observed in Inflation rate which is about 13.64499 was dispersed.

\subsubsection{Diagnostic Tests}

In this section the results of test for normality, multicollinearity, and heteroscedasticity, were presented by using Shapiro Wilk test, variance inflation factor, BrushPagan test, respectively. From the estimated test the Prob $>\mathrm{Z}$ is 0.185 . That means the estimated result occurred is $0.185>0.05$, so the null hypothesis is accepted that indicates the residual are normally distributed. The mean of VIF is less than ten $(3.38<10)$, implying that no multicollinearity problem among variables. If mean of VIF value greater than 10 and 1/VIF value greater than one, we can say there is multicollinearity. However, from this study of estimation result is the VIF value less than 10 and 1/VIF less than 1 , implying this study is no problem of multicollinearity. Additionally from the estimation result, we can compare critical prob $>$ chi2 greater than 0.05 , and the chi 2 is also low which is 1.90 , this means there is no problem of hetroskedasticity, because $0.05<0.1680$, which implies the model is homoscedasticity.

\subsubsection{Unit Root Test of Stationary}

This study uses dickey fuller (DF) test to analysis or investigate stationary of variables. It also shows the order of integration. If the calculated dickey fuller is greater than the tabulated (critical) value at a given level, the time series variable is stationary at the given order.

Table 1. Augmented Ducky-Fuller (ADF) unit root testing.

\begin{tabular}{llll}
\hline Variables & Summary of t- statistics & P-value at 5\% of critical & Order of integrated \\
\hline GDP & 4.284 & 1.691 & $\mathrm{I}(0)$ \\
FDI & 2.174 & 1.691 & $\mathrm{I}(0)$ \\
INF & 5.507 & 1.691 & $\mathrm{I}(0)$ \\
TRO & 4.474 & 3.564 & $\mathrm{I}(1)$ \\
LF & 2.400 & 1.691 & $\mathrm{I}(0)$ \\
HK & 4.480 & 3.564 & $\mathrm{I}(1)$ \\
GCF & 5.189 & 1.691 & $\mathrm{I}(0)$ \\
GDS & 2.206 & 1.691 & $\mathrm{I}(0)$ \\
INFS & 4.765 & 1.696 & $\mathrm{I}(1)$ \\
\hline
\end{tabular}

Source: Stata version 13 computed result based on data from NBE.

From the above result not each variables are stationary at level, because only GDP, FDI, LF, INF, GDS and GCF are stationary at I (0) and the other three left variables have unit root test and became stationary at I (1) or (station at $1^{\text {st }}$ difference).

Based on the Empirical aspects and the real estimated results of the model, the following hypothesis was identified in table 2 .

Table 2. Shows that the real estimated hypothesis identified and the decision rule of the estimated result obtained from the assessed data in this study.

\begin{tabular}{|c|c|c|c|}
\hline & Null hypothesis & Alternative hypothesis & Decision rule \\
\hline Regarding the relationship of target variable and GDP. & $\begin{array}{l}\text { H0: FDI\&GDP has negative } \\
\text { relationship }\end{array}$ & $\begin{array}{l}\text { H1: FDI\&GDP has positive } \\
\text { relationship }\end{array}$ & Hence $\mathrm{H} 1$ is accepted \\
\hline Regarding the nature of time series. & H0: OLS is not appropriate & $\mathrm{H} 1$ : OLS is appropriate & Hence $\mathrm{H} 1$ is accepted \\
\hline $\begin{array}{l}\text { Regarding to the variety of tests for unit roots or } \\
\text { stationary of time series }\end{array}$ & $\begin{array}{l}\text { H0: Each time series contains a } \\
\text { unit root }\end{array}$ & $\begin{array}{l}\mathrm{H} 1 \text { : Each time series is } \\
\text { stationary }\end{array}$ & Thus, H0 is accepted. \\
\hline
\end{tabular}

Hence, the null hypothesis was accepted and the alternative was rejected. 


\subsection{Econometrics Analysis}

\subsubsection{Long Run Estimation result (OLS)}

Table 3. Showed the output of long run estimation results.

\begin{tabular}{llllll}
\hline GDP & Coef & Std. Err & t-value & P>|t| & [95\% Conf. Interval] \\
\hline FDI & .0055749 & .001489 & 3.74 & 0.001 & .0025238 \\
INF & -4.317853 & 5.059756 & -0.85 & 0.401 & -14.68229 \\
GCF & .0185408 & .0028384 & 6.53 & 0.000 & .0086267 \\
HK & 35.65295 & 22.90371 & 1.56 & 0.131 & .0127266 \\
TRO & .0040519 & .0023831 & 1.70 & 0.100 & -11.26317 \\
GDS & .0031901 & .001158 & 2.75 & 0.010 & -.0008298 \\
INFS & 1.756033 & .8780988 & 2.00 & 0.055 & .0008181 \\
LF & .004869 & .0106634 & 0.46 & 0.651 & -.0426709 \\
Constant & 1498.289 & 374.6029 & 4.00 & 0.000 & -.016974 \\
\hline
\end{tabular}

R-squared $=0.9665$, Adj R-squared $=0.9570$ Prob $>F=0.000$.

Source: Own computations based on data from NBE.

The estimated model is specified as follows:

$$
\begin{gathered}
\mathrm{GDP}=\beta_{0}+\beta_{1} \mathrm{FDI}+\beta_{2} \mathrm{INF}+\beta_{3} \mathrm{TRO}+\beta_{4} \mathrm{LF}+\beta_{5} \mathrm{Hk} \\
+\beta_{6} \mathrm{GCF}+\beta_{7} \mathrm{GDS}+\beta_{8} \mathrm{INFS}+\mathrm{u}_{\mathrm{i}}
\end{gathered}
$$

$\mathrm{GDP}=1498.289+0.0056 \mathrm{FDI}-$

$$
\begin{gathered}
\text { 4.3179INF+0.004052TRO+0.004869LF+35.653HK } \\
+0.01854 \mathrm{GCF}+0.00319 \mathrm{GDS}+1.75603 \mathrm{INFS}+\mathrm{Ui}
\end{gathered}
$$

Interpretation of the long run result of the model.

From the above regression result the F-value of 0.000 indicates that all independent variables are jointly explain the dependent variable in good manner and strong statistical significance, which enhanced the reliability and validity of the model. The R-squared (0.9665) result revealed that 96.65 percent of the variation in gross domestic product is explained by the given independent variables jointly. The remaining $3.35 \%$ of the variation in the dependent variable is presumed to be due to random variability.

In addition to that the probability values of foreign direct investment, gross domestic saving, gross capital formation and were statistically significant at $5 \%$ of significance level and infrastructural level was significant at $10 \%$ level of of significance level while the probability values of Inflation rate, Trade openness, Labor force and Human Capital investment on education variables were statistically insignificant that may be due to lack of availability of data collected from the national bank of Ethiopia.

Regarding to coefficient of the explanatory variables regression result, from the above estimated growth equation model the sign of the determinants of gross domestic product was valid with the theories of economic growth. Foreign direct investment, trade openness, labor force, human capital investment on education, gross capital formation, gross domestic saving and Infrastructural level have positive relation with the GDP and Inflation rate has negative relation. The constant term result indicates that regardless of the all explanatory variables, the growth of gross domestic product estimated to be about 1498.289 in million birr.

From the long run estimation result a $1 \%$ increasing by the foreign direct investment leads to the $0.5575 \%$ increasing the growth of the country other remains constant. Inflation rate which has negatively affect the GDP of the country means that a $1 \%$ increasing of inflation rate result to the about 4.32 amount decreases the growth domestic product, other things remain constant. Gross capital formation has positive impact on the economic growth and significant. A one percent increase in gross capital formation result to $1.854 \%$ increase the growth of the country's GDP. Like these variables, a one percent increasing of the trade openness gross domestic saving and labor force cause to change the percentage of their own coefficients. Similarly a one unit change of human capital and infrastructure result to change the gross domestic product of the country, cetresbarubes.

The result of the above estimation reports that as the trade openness, human capital, labor force and inflation rate are insignificant. The insignificance of trade openness relationship is because of as the country opens up to trade demand for country's abundant factor do not significantly increase and this would not increase the price of these factors (do not increase the return of owners of these factors). Human capital expenditure on education is insignificant impact on country's economy. This is because of that; the student doesn't contribute to the country's economy, because they are not included in the working age groups. As the consumer price index of the country fluctuated over the year the effect of the inflation rate was also insignificant on the economic growth. Even if the contribution of labor force forwarded and increase the GDP of the country it is insignificant. This is due to that labor force employed in foreign company has more significant for foreigners rather than domestic growth.

\subsubsection{Short Run Error Correction Model (ECM)}

After the acceptance of long-run coefficients of the growth equation, the short-run ECM model is estimated. The error correction term (ECM), indicates the speed of adjustment to restore equilibrium in the dynamic model. It is a one lagged period residual obtained from the estimated dynamic long run model. The coefficient of the error correction term indicates how quickly variables converge to equilibrium. Moreover, it should have a negative sign and statistically significant at a 
standard significant level (i.e. p-value should be less than $0.05)$.

Table 4, Results of short run Error Correction model estimation result.

\begin{tabular}{llll}
\hline \multicolumn{2}{l}{ Dependent variable is GDP } & & \\
\hline Regressors & Coefficient & Standard error & p-value \\
\hline DFDI & 0.0003108 & 0.0014107 & 0.826 \\
DINF & -9.411377 & 3.800523 & 0.013 \\
DTRO & -0.012905 & 0.0042253 & 0.002 \\
DLF & 0.0056791 & 0.0066387 & 0.392 \\
DHK & -31.62179 & 24.88434 & 0.059 \\
DGCF & 0.0024958 & 0.0079534 & 0.754 \\
DGDS & 0.0052508 & 0.0039562 & 0.076 \\
DINFS & 0.6055889 & 0.9202046 & 0.510 \\
DCONS & -265.8364 & 100.2453 & 0.008 \\
ECMT $(-1)$ & -0.1939352 & 0.05599 & 0.001 \\
\hline
\end{tabular}

R-squared $=0.8507$.

Source: Own computations based on data from NBE.

The error correction coefficient, estimated at -0.1939352 is significant at $5 \%$ of significance level and it is the correct negative sign, and imply low speed of adjustment to equilibrium. Moreover, the coefficient of the error term (ECM1) implies that the deviation from long run equilibrium level of real GDP in the current period is corrected by $19.39352 \%$ in the next period to bring back equilibrium when there is a shock to a steady state relationship. The coefficient of determination (R-squared) is explaining that about $85.07 \%$ of variation in the GDP is attributed to variations in the explanatory variables in the model. This show goodness of fit of the above model (R2) shows that $85.07 \%$ of the total variation in the dependent variable GDP is explained by the independent variables in the model.

From the table 4 above the researcher identified the short run growth mode as follow:

$$
\begin{gathered}
\mathrm{GDP}=-265.8364+0.0003108 \mathrm{FDI}-9.411377 \mathrm{INF}- \\
0.012905 \mathrm{TRO}+0.0056791 \mathrm{LF}-31.62179 \mathrm{HK} \\
+0.0024958 \mathrm{GCF}+0.0052508 \mathrm{GDS}+0.6055889 \mathrm{INFS}-
\end{gathered}
$$

$$
0.1939352 \text { ECM-1 }
$$

This short run equation shows that all explanatory variables have similar impact on the growth model like in the long run relation, except trade openness and human capital. in the short run independent variables such as inflation, trade openness are statistically significant at $5 \%$ of significance and human capital, gross domestic saving are significant at the $10 \%$ significance level. Foreign direct investment has positive impact on the growth in the short run analysis similar to the long run. Without the independent variables effect the growth of GDP is about -265.8364 unit in the short run. A one percent increase FDI result $0.03108 \%$ increase the growth of the country.

The short run dynamics are captured through the individual coefficients of the differenced terms. These coefficients are called the adjustment coefficient. The coefficient of the error correction term for the equation is negative as expected but it is significant at $5 \%$ significance level. This tells us that there is a reasonable adjustment towards the long-run steady state. The error correction term 0.1939352 ECM shows that about 19.3935 percent of the deviation of the actual growth of the country from its equilibrium value is eliminated every year. This shows that any short run deviation of per capita GDP from the long run equilibrium is gradually converge to equilibrium.

\section{Conclusion and Recommendation}

\subsection{Conclusion}

This paper was examined impact of foreign direct investment (FDI) on the Ethiopian economic growth (GDP) by using time series data over the period 1982 to 2018. Descriptive analysis was applied to show the trend of both dependent variable (GDP) and included independent variables.

To determine relationship among the variables, simple regression or OLS (ordinary least square) model was applied for the long run process and error correction model (ECM) for short run analysis. Before applying an econometric estimation by using simple regression model, all the variables are tested for their time series properties (stationary properties) using the ducky fuller (DF) tests. As a result, some variables were integrated of order zero or stationary at level, while some of it were integrated of order one I (1) or stationary at first difference.

Generally Findings of econometric analysis can be summarized as follows:- From the empirical regression OLS result, showed that the target variable, Foreign direct investment has a positive impact on the Ethiopian economic growth in the short run and long run relationship. Labor force, Human capital, trade openness, gross capital formation, gross domestic saving and infrastructure have direct relation and encourage the economic growth in Ethiopia. These explanatory variables have positive contribution on economic growth of country. The effect of trade openness and human capital expenditure are negative and significant on growth in the short run estimated result. These negative impacts were existed after the model was two lagged years. Errorcorrection model (ECM) has been used to support the existence of a stable long-term relationship and confirm a deviation from the long-term equilibrium following a shortterm shock corrected by approximately 19.4 percent after each year.

\subsection{Recommendations}

Considering the conclusions made on the impact of foreign direct investment on economic growth, the following policy implications or recommendations are identified;

Even if the foreign direct investment has positive impact on the economic growth in Ethiopia, the amount of contributions obtained from that is not much more enough, then the government should initiatives the foreign direct investment inflows into Ethiopia and open the ways for foreign investment further.

The Ethiopian investment agency should promote the FDI that offer a good match with Ethiopia's need and 
opportunities. The trend of foreign direct investment was more or less fluctuated, thus the investment strategies should try's to avoid this fluctuation as much as possible.

The role of infrastructural services like road transportation, communication services and trade openness and working force like labor force have a great role for the attraction of foreign investors for investment. Then these essential variables should be put in the huge consideration by the Ethiopian investment agency as the contribution did not fall to motivate the growth and also all Ethiopians needs to increase the improved infrastructure, human capital and Labour forces to internalize and fully utilize the benefit of foreign investment inflows.

\section{References}

[1] Agrawal, G., \& and Khan, M. A. (2011). Impact of FDI on GDP: Comparative study Chana and India. International Jounal of Business and Management, 6 (10), 71-79.

[2] Carp, L. (2012). Analysis of the relationship between FDI and Economic Growth Literature review study. USV annals of Economics and Public Administration Volume 12, Issue 1 (15).

[3] Damooei, J., \& and Tavakoli, A. (2006). The effects of Foreign Direct Investment and Imports on Economic Growth a Comparative analysis of Thailand and Phillipians (1970-1998) (Vol. The journal of Developing Areas volume39).

[4] Denisia, V. (2010). Foreign Direct Investment Theories; An Overviews of the main FDI Theories.

[5] Getnet, A., \& and Hirut, A. (2006). Determinants of FDI in Ethiopia, time series analys.
[6] Li, X., \& and Liu, X. (2005). Foreign Direct Investment and Economic Growth; An Increasingly Endogenous Relationship. World development 33 (3), 393-407.

[7] Meskerem, D. M. (2014). Impact of Foreign Direct Investment on Economic Growth of Ethiopia: Time series empirical analysis, 1974-2011. Addis Ababa.

[8] Morisset, J. P., \& and Pirnia, N. (2009). How tax policyb and incentives affect on FDI a review.

[9] Ramla, R., \& and Zhang, K. (2002). Foreign Direct Investment and Economic Growth in Ethiopia.

[10] Reiter, S., \& and Kevin, S. (2010). Human Development and Foreign Direct Investment in Developing Countries: The Influence of FDI policy and Corruption. World Development 38 (12), 1678-1691.

[11] Solomon, M. (2008). Determinants of Foreign direct Investment in Ethiopia. Mastrticht, Netherlands.

[12] Tang, S., \& S, a. S. (2008). Foreign Direct Investment and Economic Growth in China: time series analysis. United Nation University: World Institute for development Economic research.

[13] Tibebu. T (2014), The relationship between FDI and domestic private investment over the period 1970-2012 in Ethiopia.

[14] UNCTAD. (2015). World Investment Report 2015: Reforming International Investment Governance. New York and Geneva.

[15] Velde, D. (2006). Foreign Direct Investment and Development: An historical perspective.

[16] Wondoson. (2011). The impacts of FDI capital inflows on economic growt, saving and investment. Addis Ababa University, Ethiopia. 